\title{
Cut slopes failures on the Triassic beds in Coimbra, Portugal
}

\author{
Quinta-Ferreira, Mário${ }^{1}$; Andrade, Pedro S. ${ }^{2}$; Lemos, Luís ${ }^{3}$; Saraiva, António ${ }^{4}$ \\ ${ }^{1,2,4}$ Department of Earth Sciences, Geosciences Center \\ Largo Marquês de Pombal. University of Coimbra \\ 3000-272 Coimbra, Portugal
}

Phone: +351239860531; Fax: +3512398605001

${ }^{1}$ mqf@dct.uc.pt, ${ }^{2}$ pandrade@dct.uc.pt, ${ }^{4}$ asaraiva@dct.uc.pt

${ }^{3}$ Department of Civil Engineering, Civil Engineering Center

Polo II, University of Coimbra

Rua Luis Reis dos Santos

3030-788 Coimbra

llemos@dec.uc.pt

\begin{abstract}
Several cut slope failures that occurred in the Triassic “Grés de Silves”, in the area of Areeiro in Coimbra, Portugal, are analysed. They developed along thin mudstone layers dipping at some $16^{\circ}$ towards the face of the excavation. The failures mainly occurred after periods of intense rainfall, in some cases immediately after the excavation of the slope and in some cases have continued for the seven years since, even where the slope height was only a few metres. The conditions leading to the failures were investigated in the field and in the laboratory. It was concluded that the main factors inducing the slope failure are a conjugation of the geological structure and the reduction in the shear strength of the mudstones when the excavation results in dilation, such that fissures open allowing the ingress of water.
\end{abstract}

Keywords Slope stability, Mudstone, Risks, Coimbra. 
Résumé $\quad$ On analyse plusieurs ruptures de pentes d'excavation qui se sont produites sur le "Grés de Silves" du Trias, dans la zone de l'Areeiro à Coimbra, au Portugal. Ces ruptures se sont développées le long des couches de siltite, d'épaisseur réduite, inclinée $16^{\circ}$ vers l'extérieur des pentes, surtout après des périodes de pluies intenses. Les ruptures se sont produites dès immédiatement après l'excavation des pentes, et se sont étendues jusqu'au présent, sept ans plus tard, même en pentes de quelques mètres de hauteur. Les conditions déclenchent les ruptures ont été étudiées “in situ” et en laboratoire. On a conclu que les causes principales des ruptures de pente sont la conjugaison de la structure géologique et de la dégradation du siltite, qui souffre une réduction drastique de résistance au cisaillement lorsque l'excavation provoque la décompression, permettant l’ouverture des fissures et l'accès à l'eau.

Mots clés Stabilité de pentes, Siltite, Risques, Coimbra

\section{Introduction}

Urban development in areas of steep topography tends to require cut and fill excavations to improve accessibility and usable space. On poor quality ground, or when unfavourable conditions are present, changing the natural slope geometry frequently leads to slope instability. When persistent rainfall occurs, the reduction of the safety factor may be quite significant, leading to an increase in the number of slope failures (Chleborad 2000, Schuster and Highland 2007, Quinta-Ferreira et al. 2005, 2006, Quinta-Ferreira 2007). However, predicting the exact conditions which lead to slope failure is in most cases a difficult task. Whilst the geological conditions are important, human intervention is frequently responsible for the triggering of the failures and the increase in damage. Geological features, even those too limited to record cartographically, can be quite important for the stability of the terrain.

As the occurrence of slope failures in the Coimbra area has recently caused significant damage and huge economic losses (Quinta-Ferreira 2007, Lemos and Quinta-Ferreira 2004), a better understanding of the causes of such failures and the prevention and minimization of future slides is essential (QuintaFerreira and Quinta-Ferreira 2004). This paper reports an analysis of some problematic slopes in Areeiro, Coimbra, considering the timing of the failures, the causes and consequences, stabilization procedures and stability evaluations.

\section{Geological setting}

In the area of Areeiro, the bedrock is the Triassic sandstone known as “Grés de Silves” (Fig. 1) overlying Proterozoic black schist. The regional geological structure is a monocline dipping gently to the west. Several faults locally modify the orientation of the bedding. The sandstone of the "Grés de Silves" is usually covered by a thin residual soil, or alluvial deposits at the bottom of the valley, which obscure a probable fault alignment. 
According to Miranda et al. (2010), the sandstone outcropping in Areeiro belongs to the units A1, A2 and B1 of the Triassic sedimentary sequence defined by Palain (1976). The depositional sequence, from the base upwards, ranges from coarse material in layers of irregular geometry and wide grain size distribution (mainly sandstone but occasionally with cobbles or boulders) at the base of each sequence (units A1, B1), to well-defined layers of sandstone and mudstone (units A2 and B2). The reddish sandyconglomeratic layers were formed by fluvial deposition, while the grey mudstone (silt and clay) layers correspond, essentially, to shallow-water lacustrine sedimentation (Miranda et al. 2010). The transition from the irregular sandstone layers to the well-defined mudstone layers is emphasised by the change in colour from red to grey. The outcropping units A1 and A2 are equivalent to the Conraria Formation while unit B1 corresponds to the lower part of the Castelo Viegas Formation (Azerêdo et al. 2003).

Before significant human intervention in the area, the original ground surface on the east side of the valley had an inclination of $8^{\circ}$, while on the west side of the valley it was $12^{\circ}$ (Fig. 1 ). This difference can be attributed to the gentle dip (c. $16^{\circ}$ ) of the Triassic beds to west, although this is broken by several faults (Fig 2). The surface weathering and erosion was more intense in the softer mudstone layers.

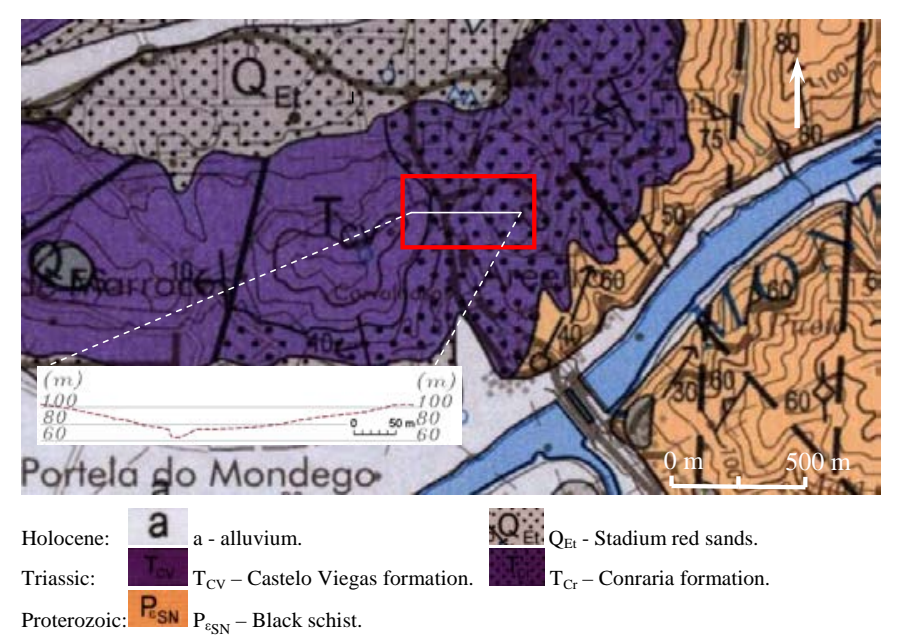

Fig. 1 Geology of the region around Areeiro (modified from Soares et al. 2007). The rectangle locates the study area

\section{Episodes of slope failure}

The locations of the failed slopes are presented in Fig. 2 and are numbered from 1 to 4 in chronological order (Table 1). All the failures reported in this work occurred along mudstone layers in the transition between units A1 to A2 of the “Grés de Silves”, or within unit A2 of the Conraria Formation (Fig. 2b). 


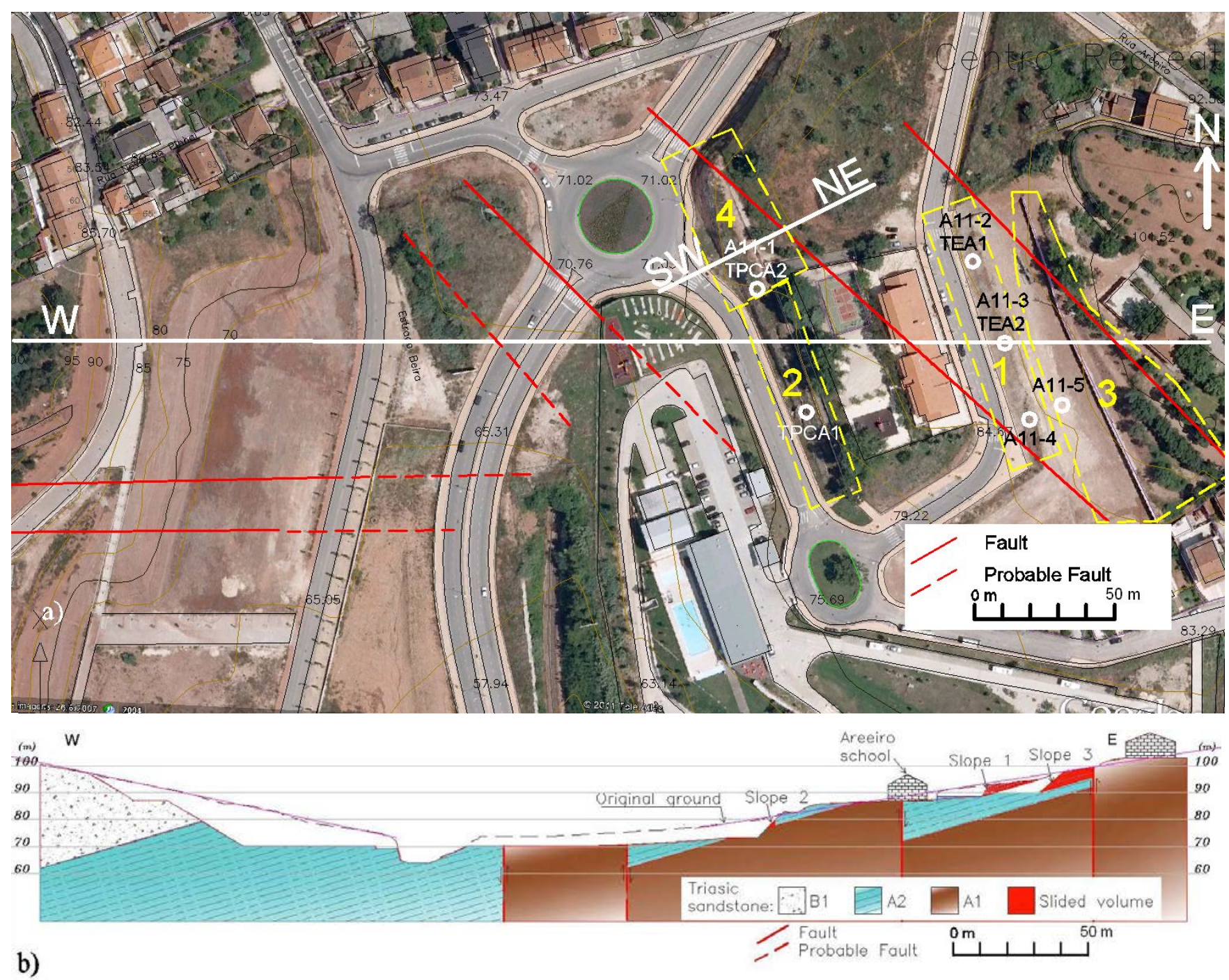

Fig. 2 a Location of the four cut slopes studied (modified from Tele Atlas/Google Earth) overlayed by a topographic survey map: 1 street to “Quinta do Areeiro”, 2 Areeiro School, 3 “Quinta do Areeiro”, 4 Areeiro roundabout. The main faults and sampling locations of the mudstone are presented. $\mathbf{b}$ cross section interpretation of the geological structure. Triassic:

Conraria formation (A1 and A2), Castelo Viegas formation (B1) 
Table 1 Chronological sequence of failures

\begin{tabular}{|c|c|c|c|c|}
\hline Slope $\mathrm{N}^{\mathrm{o}}$ & Excavation & Failure events & $\begin{array}{c}\text { Failed } \\
\text { Volume }\left(\mathrm{m}^{3}\right)\end{array}$ & Remarks \\
\hline $\begin{array}{l}\text { (1) Street to } \\
\text { "Quinta do } \\
\text { Areeiro" }\end{array}$ & $\begin{array}{c}2004 \\
\text { (February 23-27) }\end{array}$ & $\begin{array}{c}2004 \\
\text { (February 28) }\end{array}$ & $\begin{array}{c}3000 \\
(100 * 12 * 2.5)\end{array}$ & $\begin{array}{l}\text { P-3=16; P-15=6; P-30=85 } \\
\text { Mudstone layers dipping } 16^{\circ}\end{array}$ \\
\hline (2) Areeiro School & 2004 & $\begin{array}{c}2005 \\
\text { (December 22) }\end{array}$ & $\begin{array}{c}170 \\
(40 * 2.5 * 1.7)\end{array}$ & $\begin{array}{l}\mathrm{P}-3=0 ; \mathrm{P}-15=4 ; \mathrm{P}-30=121 \\
\text { Mudstone layers dipping } 15^{\circ} \text {. Destruction } \\
\text { of drainage system and sidewalk wall }\end{array}$ \\
\hline & & $\begin{array}{c}2007 \\
\text { (December 06) }\end{array}$ & $\begin{array}{c}48 \\
(8 * 4 * 1.5)\end{array}$ & $\begin{array}{l}\mathrm{P}-3=1 ; \mathrm{P}-15=68 ; \mathrm{P}-30=68 \\
\text { Destruction of the drainage system }\end{array}$ \\
\hline $\begin{array}{l}\text { (3) “Quinta do } \\
\text { Areeiro” }\end{array}$ & $\begin{array}{c}2006 \\
\text { (March) }\end{array}$ & 2006 (March 24) & $\begin{array}{c}4620 \\
(77 * 15 * 4)\end{array}$ & $\begin{array}{l}\mathrm{P}-3=40 ; \mathrm{P}-15=44 ; \mathrm{P}-30=104 \\
\text { Mudstone layers dipping } 16^{\circ}\end{array}$ \\
\hline \multirow[t]{2}{*}{$\begin{array}{l}\text { (4) Areeiro } \\
\text { roundabout }\end{array}$} & 2004 & 2010 (April 17) & $\begin{array}{c}119 \\
(14 * 5 * 1.7)\end{array}$ & $\begin{array}{l}\mathrm{P}-3=20 ; \mathrm{P}-15=13 ; \mathrm{P}-30=77 \\
\text { Mudstone layers dipping } 15^{\circ} \text {. Destruction } \\
\text { of the sidewalk and side wall }\end{array}$ \\
\hline & & 2011 (May 1) & $\begin{array}{c}136 \\
(20 * 4 * 1.7)\end{array}$ & $\mathrm{P}-3=36 ; \mathrm{P}-15=55 ; \mathrm{P}-30=56$ \\
\hline
\end{tabular}

P-3 - accumulated rainfall in the three days before the failure

$\mathrm{P}-15$ - accumulated rainfall in the fifteen days, before P-3

P-30 - accumulated rainfall in the thirty days, before P-3

\section{Street to "Quinta do Areeiro" (Slope 1)}

The first failure took place at the end of February 2004 after the excavations for the street to "Quinta do Areeiro” (Fig. 3). A landslide approximately $100 \mathrm{~m}$ long and some $12 \mathrm{~m}$ wide occurred following a 1.5 to $2.5 \mathrm{~m}$ high excavation. The slip occurred where the mudstone beds dip at some $16^{\circ}$, following a period of rainfall (Table 1). Chleborad (2000) defined the parameters P-3 and P-15 as the accumulated rainfall (in millimetres) in the three days or 15 days before the failure. In this study, the parameter P-30 is introduced corresponding to the accumulated rainfall in the thirty days before P-3. Remediation involved removing the failed ground and reducing the height and angle of the slope (Fig. 3b).
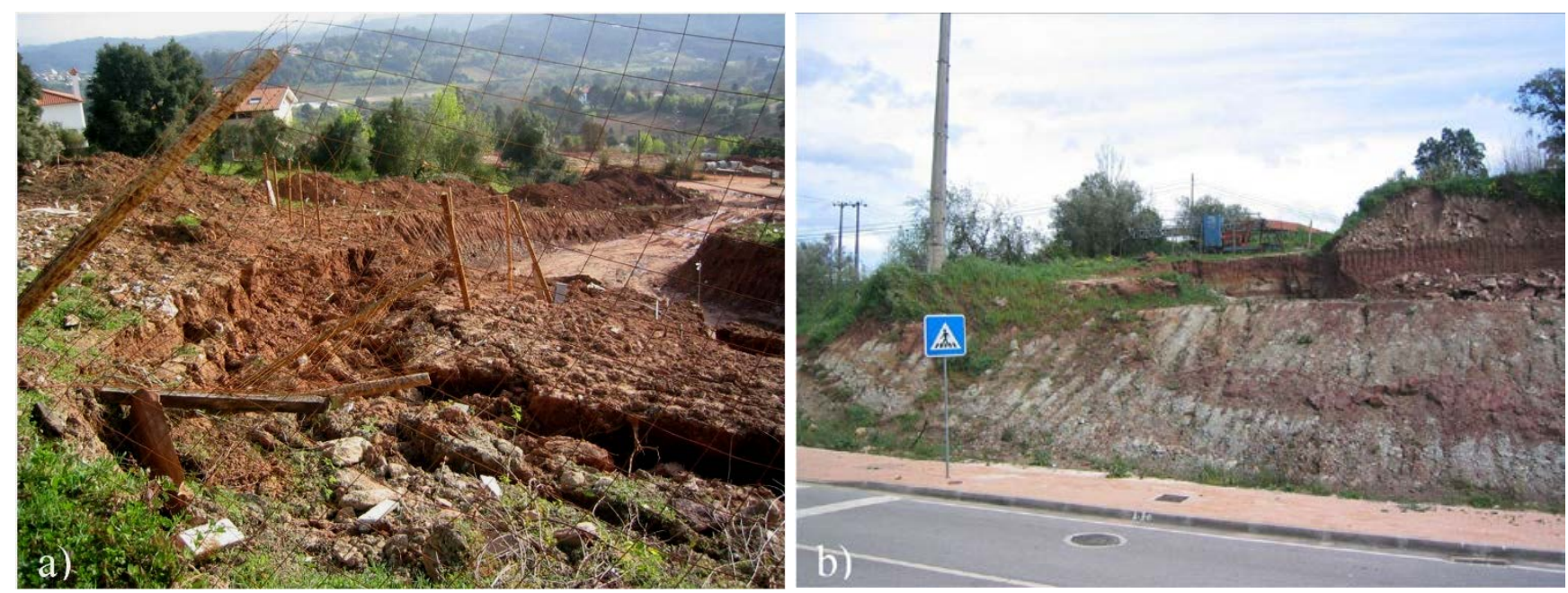

Fig. 3 Slide of the street to "Quinta do Areeiro" cut slope: a planar slide following excavation during construction, at the end of February 2004 and $\mathbf{b}$ geometry of the slope after removal of the failed ground, and final reshaping 


\section{Areeiro School (Slope 2)}

The cut slope of Areeiro School resulted from the excavation of the access road to the Coimbra Camping Park, which created an excavation from $10 \mathrm{~m}$ high close to the Areeiro roundabout, decreasing to zero at the entrance to the Camping Park. Units A1 and A2 of the "Grés de Silves” (Palain 1976) are exposed in this slope; the transition being marked by a grey mudstone layer, dipping $15^{\circ}$ to west, towards the face of the slope (Fig. 4ab). Following the excavation works in 2004, two episodes of instability have occurred, in December 2005 and December 2007 (Table 1 and Fig. 4).

In 2005 a planar slope failure destroyed the superficial drainage system and the small retaining wall along the sidewalk. The remediation works carried out in early 2006 included the removal of the failed material, the reconstruction of the drainage and the construction of a free-draining rock buttress at the bottom of the slope. The affected area was covered with a biodegradable erosion control blanket to encourage re-vegetation. The small sidewalk wall at the slope's toe was also re-built.

In December 2007, part of the undisturbed terrain to the right of the 2005 slide suffered a planar failure similar to the one that occurred in 2005, but of smaller dimensions (Fig. 4c and Table 1). At present, this failure still waits remediation.

The interval between the intense precipitation and the occurrence of the failure is the largest of the six landslides studied. This is attributed to the reduced infiltration into the ground as a result of both the school building and the asphalted playground, which increased the time taken for sufficient water to reach the slip surface and trigger the slide. 

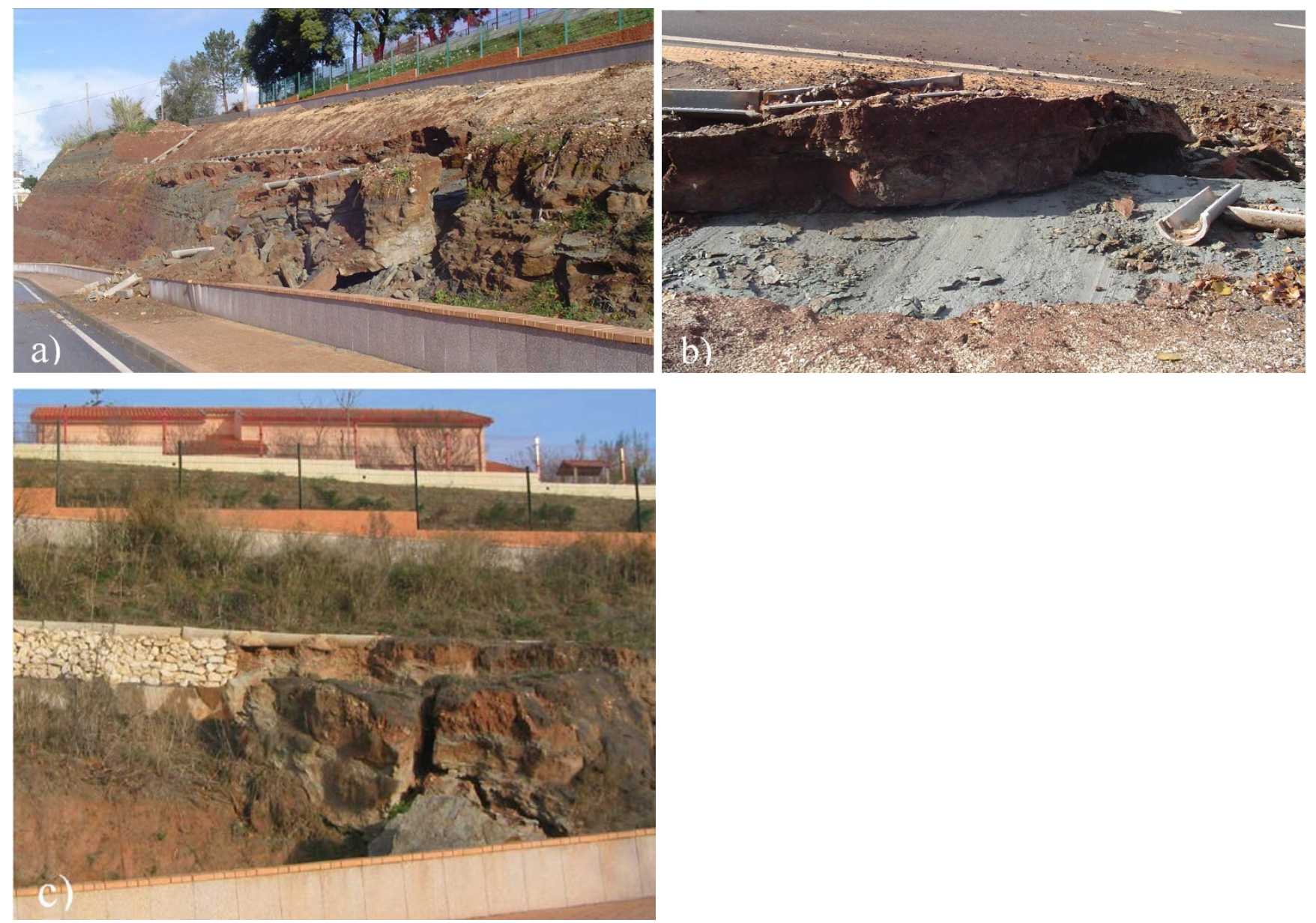

Fig. 4 Planar failures in the Areeiro School slope. December 2005: a landslide occurred along the mudstone stratification, b slided block and slickenlines on the mudstone bedding plane. December 2007: c reactivation of the failure to the right of the 2005 slide

\section{"Quinta do Areeiro"}

Enabling works for the construction in Quinta do Areeiro, carried out in March 2006, involved the excavation of a sub-vertical slope, up to $>5 \mathrm{~m}$ high (slope 3 of Fig. 2), which it was intended to stabilize with a gabion retaining wall. Shortly after excavation, a planar failure occurred along a mudstone layer intersecting the base of the slope, in the central and southern areas of the excavation (Fig. 5). The presence of a sub-vertical $\mathrm{N} 48^{\circ} \mathrm{W}$ fault at the rear of the failed block and oblique to the excavation face, limited the slide volume but a $2 \mathrm{~m}$ wide, 3-5 m high tension crack developed. The slide destroyed most of the gabion wall that was under construction. The grey to greenish mudstone layer on which the landslide moved is orientated $\mathrm{N}^{\circ} 6^{\circ} \mathrm{W}, 16^{\circ} \mathrm{SW}$. The mudstone layer was $0.1 \mathrm{~m}$ to $0.3 \mathrm{~m}$ thick but composed of alternating light and dark coloured thin beds (only a few millimetres thick) related to the lacustrine sedimentation processes (Fig. 6). The stabilization of this slope was achieved by removing most of the failed mass above the sliding surface, re-shaping the slope and re-building the gabion retaining wall. 


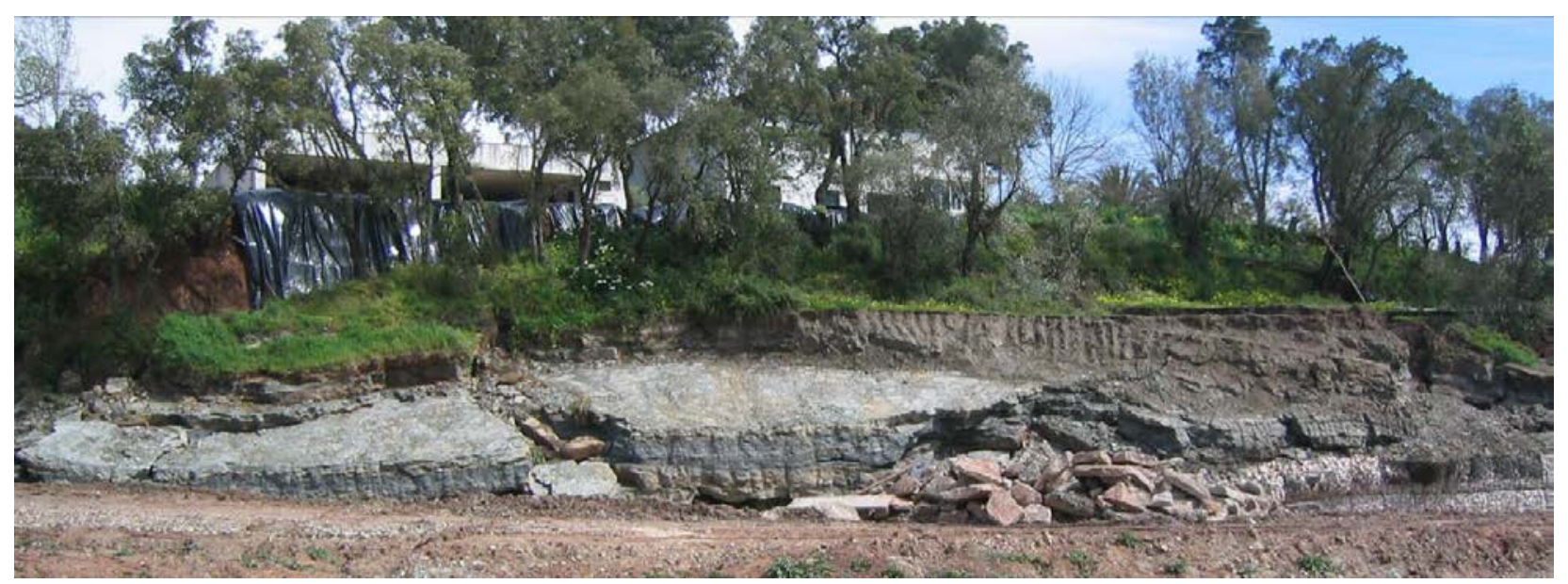

Fig. 5 Overview of the failed slope of “Quinta do Areeiro” (March 2006). The black plastic liner in the background highlights the fault scarp oriented $\mathrm{N} 48^{\circ} \mathrm{W}$, subvertical, revealed by the slide
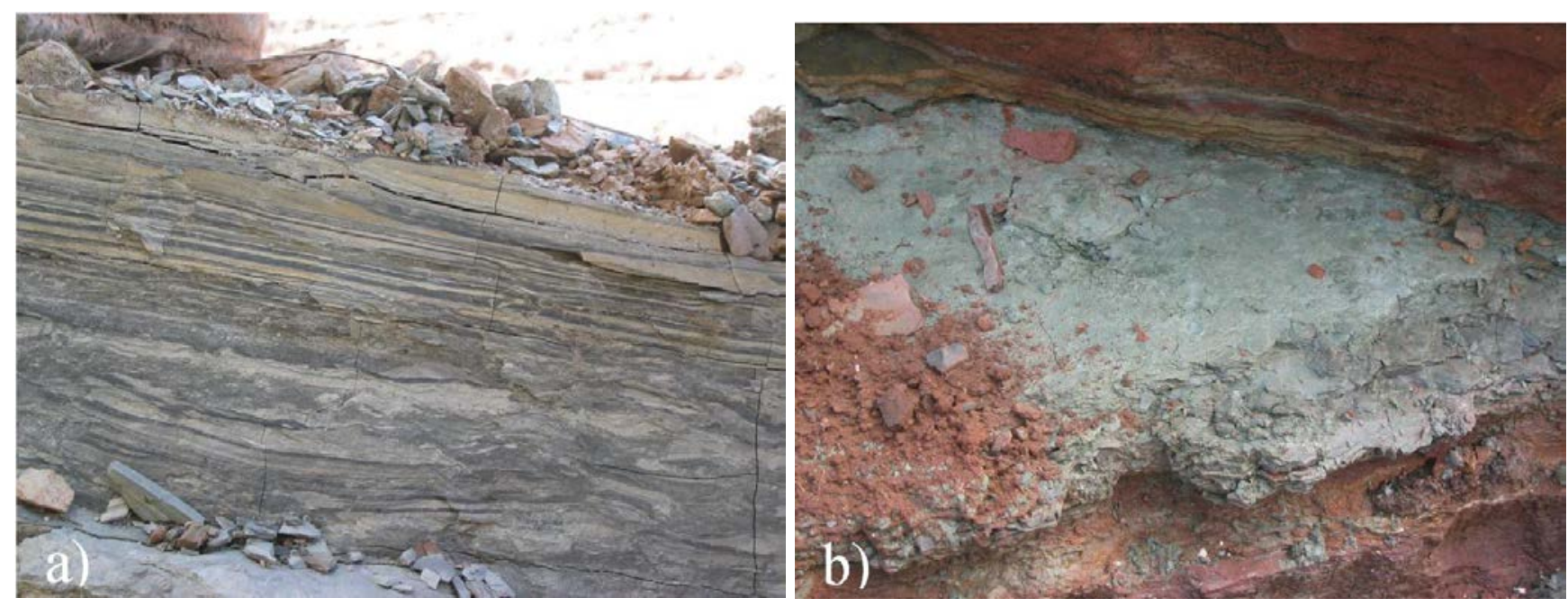

Fig. 6 Details of the mudstone layer responsible for the landslide of "Quinta do Areeiro”: a alternating millimetric layers showing light and dark colours and $\mathbf{b}$ greenish slide mudstone surface, in the southern border of the landslide

\section{Areeiro Roundabout}

In the summer of 2009 it became apparent that the slope of the Areeiro roundabout (slope 4 of Fig. 2), was developing a planar failure. The first failure occurred in mid April 2010 after a period of intense rainfall and the second a year later, in May 2011 (Fig. 7). In both cases, fallen blocks accumulated at the base of the cut slope, encroaching onto the sidewalk and part of the roundabout road pavement and posing a serious danger to pedestrians and drivers. The grey mudstone layer on which the movement occurred is clearly seen in the cut face at the transition between units A1 and A2 of the "Grés de Silves" (Palain 1973, Miranda et al. 2010). Although the fallen material was removed, the only stabilisation measure was to place a plastic liner over the surface of the slope. At present, therefore, the possibility of another slide remains, as a potentially unstable mass is still present at the top of the slope (Fig. 7). 

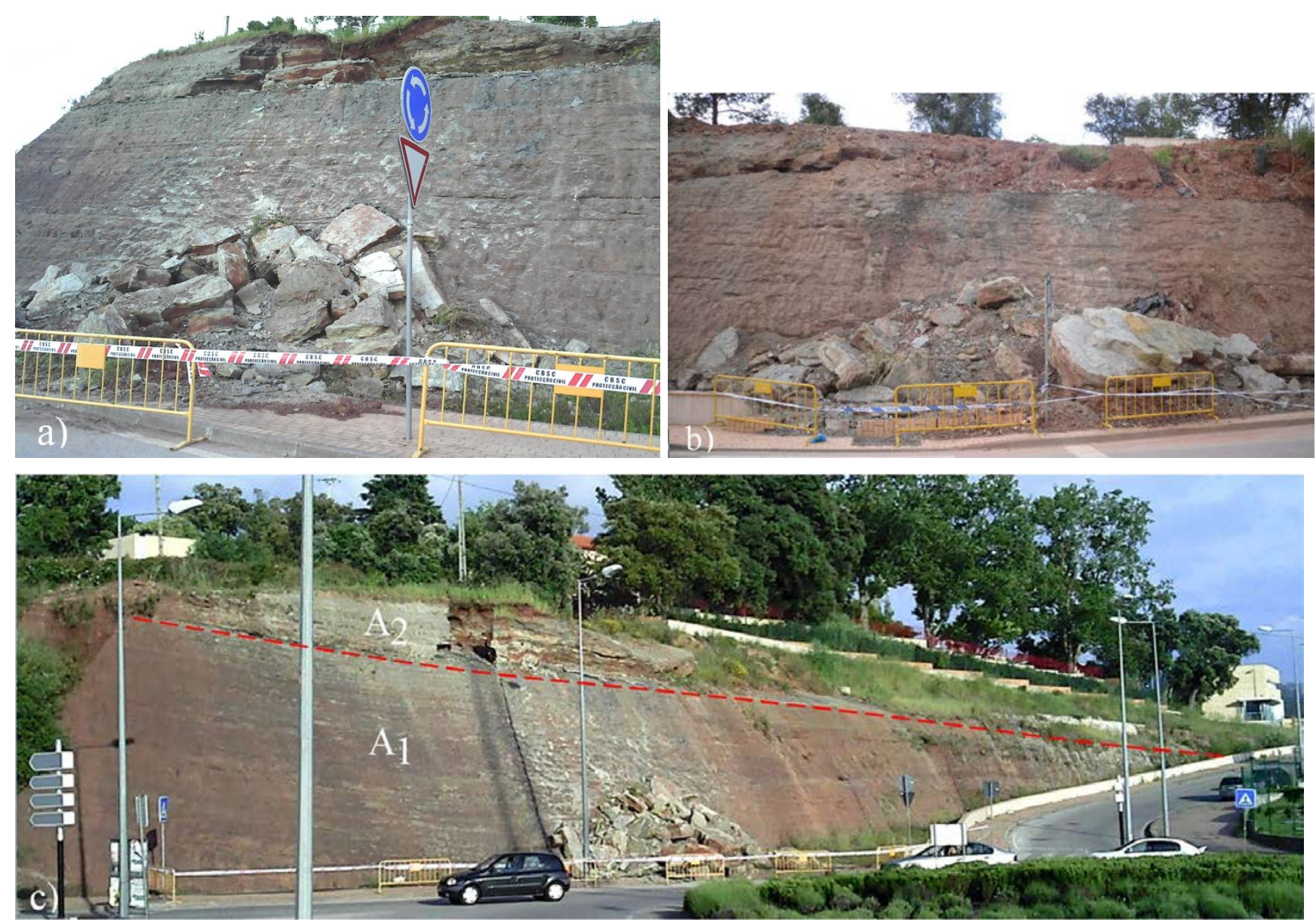

Fig. 7 Areeiro roundabout slope: a May 2011 failure, b April 2010 failure and c global view in May 2011. At left is the Areeiro roundabout slope with accumulation of fallen blocks of the 2011 slide. At centre top, it is visible the scar of the slide surface of 2010. At far right it is visible the Areeiro School slope. The grey mudstone layer responsible for the slides is highlighted by the dashed line. $\mathrm{A}_{1}$ and $\mathrm{A}_{2}$ - terms of the "Grés de Silves"

\section{Quinta da Portela}

In contrast to the successive instabilities which occurred on the east side of the valley, no significant mass movement was observed on the west side, despite the fact that this $>20 \mathrm{~m}$ high slope is the highest in the area (Fig. 8). Only minor rockfalls were observed after intense or prolonged rainfall and some water washing of the slope face. The general orientation of the slope is $N 15^{\circ}-45^{\circ} \mathrm{W} ; 10^{\circ}-27^{\circ} \mathrm{SW}$, although steeply dipping faults approximately perpendicular to the slope face result in some variability in the bedding orientation, particularly close to the faults. The absence of stability problems may be explained by the fact that the bedding dips into the slope. The upper part of unit A2 (Conraria formation) and the lower part of unit B1 (Castelo Viegas Formation) outcrop in this slope (Fig. 2, 8). 


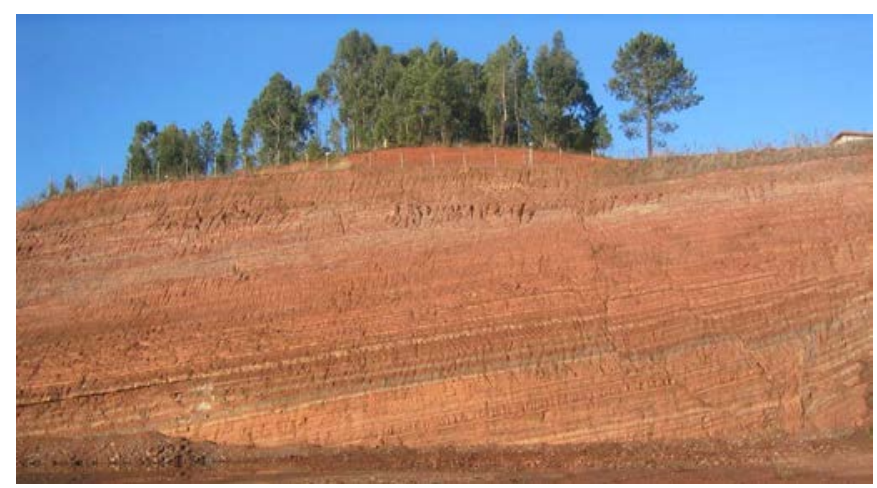

Fig. 8 View of the west cut slope of Quinta da Portela, around $20 \mathrm{~m}$ high, without any major instability features

\section{Sampling and testing}

A geological reconnaissance and a detailed structural study of the slopes (mainly joints and faults) were undertaken and nine mudstone samples collected for laboratory testing. The samples were taken from the lower part of unit A2, in layers that either had failed or were considered likely to fail (Fig. 2a). The porometry and porosity of the intact mudstone was obtained using the mercury porosimeter and X-ray diffraction, ring shear and oedometer tests were undertaken on disturbed samples.

\section{Mineralogy of the mudstone}

The mineralogy of the mudstone was studied using X-ray diffraction. The samples were manually disaggregated and a suspension was prepared in order to separate the coarse fraction from the clay fraction, based on Stokes Law. The X-ray diffraction of the coarse material revealed the presence of quartz, potassium feldspar, mica and traces of dolomite, while the clay fraction contained predominantly illite, kaolinite, and an interstratified illite-vermiculite (Fig. 9).

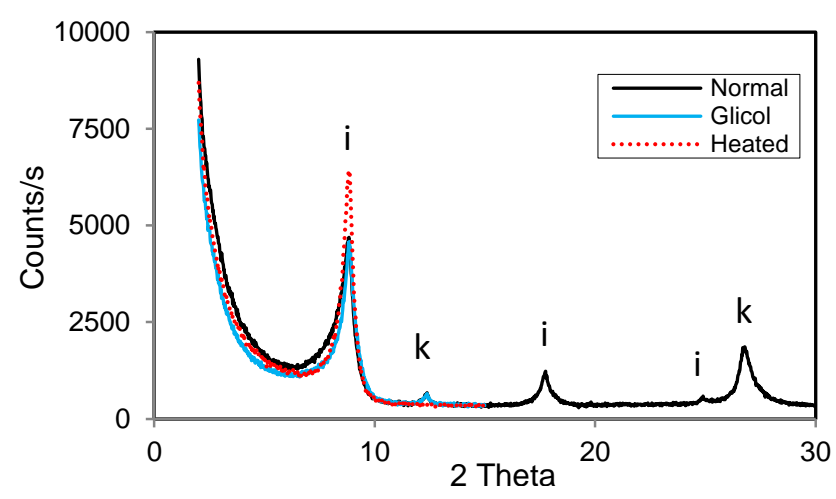

Fig 9 X-ray diffractograms of the clay-fraction of sample A11-1 collected in the slope of Areeiro School. k - kaolinite; i illite 


\section{Porometry and porosity of intact mudstone}

The rapid degradation of the internal structure of the mudstone when immersed in water prevented the determination of the porosity using the procedure based on the saturation of the sample in a vacuum (ISRM 2007). The mercury porosimeter was used instead, because it overcomes the interaction between the water molecules and the surface of the minerals. This technique determines both the total porosity and the variation of pore size through the relation between the pressure required to introduce a certain amount of mercury and the corresponding pore size, expressed by the Washburn equation (Eq. 1)

$$
\mathrm{D}=-(1 / \mathrm{P}) 4 \tau \cos \varphi
$$

Where: $\mathrm{D}$ is the pore diameter, $\mathrm{P}$ is the pressure applied, $\tau$ is the surface tension and $\varphi$ is the contact angle. The volume $\mathrm{V}$ of mercury penetrating the pores is measured directly as a function of applied pressure. According to this method, the pores are considered as cylinders, which approximate reality. The surface tension of the mercury varies with the degree of purity. The value generally accepted is 485 $\mathrm{dyn} / \mathrm{cm}$. The contact angle between the mercury and solids varies with its composition; however, in the absence of any contrary information, the value of $130^{\circ}$ is accepted. The equipment used was the Poresizer 9320 from Micrometrics.

The range of information that can be obtained is: total intrusion volume, total pore area, pore diameter, apparent volume weight, porosity intrusion volume and weight of the solids. A summary of the results obtained for the tested samples is presented in Table 2.

The total pore area is high, considering a low mercury intrusion due to the small size of the pores. As mentioned earlier, the X-ray diffractograms of the clay-fraction identified predominantly illite, kaolinite and an interstratified illite-vermiculite. Assuming the total pore area obtained by the mercury porosimeter as the specific surface, the values obtained are slightly below the results usually obtained for kaolinite and far below the ones expected for illite (Mitchell 1993).

For the five mudstone samples, the average of the pore diameter ranges from 0.03 to $0.05 \mu \mathrm{m}$, (Table 2), while the mean is between 0.01 and $0.28 \mu \mathrm{m}$, (Fig. 10), corresponding to materials with a narrow range of low pore sizes. The porosity of the five samples varies between $12 \%$ and $19 \%$ (Table 2).

Table 2 Mercury porosimeter results

\begin{tabular}{|c|c|c|c|c|c|c|}
\hline \multicolumn{2}{|c|}{ Sample $\mathrm{N}^{\mathrm{o}}$} & A11-1 & A11-2 & A11-3 & A11-4 & A11-5 \\
\hline Total pore area & $\left(\mathrm{m}^{2} / \mathrm{g}\right)$ & 11.36 & 6.51 & 6.75 & 5.36 & 12.61 \\
\hline Average pore diameter & $(\mu \mathrm{m})$ & 0.031 & 0.042 & 0.033 & 0.049 & 0.028 \\
\hline Dry unit weight $\gamma_{d}$ & $\left(\mathrm{kN} / \mathrm{m}^{3}\right)$ & 20.79 & 21.81 & 22.56 & 22.11 & 20.80 \\
\hline Real unit weight $\gamma_{s}$ & $\left(\mathrm{kN} / \mathrm{m}^{3}\right)$ & 25.56 & 25.77 & 25.85 & 25.94 & 25.51 \\
\hline Porosity & $(\%)$ & 18.64 & 15.35 & 12.73 & 14.79 & 18.46 \\
\hline
\end{tabular}




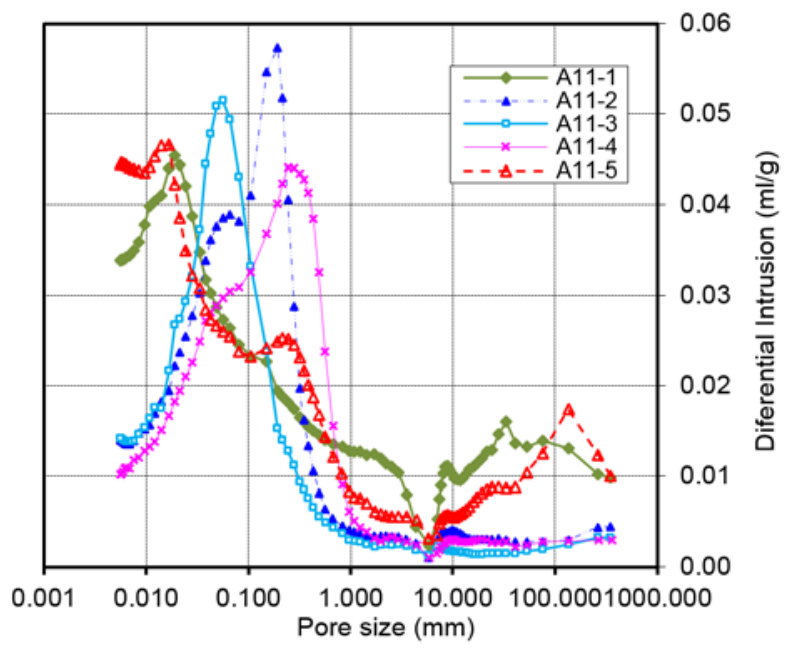

Fig. 10 Relation between the pore diameter and the differential intrusion of mercury

\section{Grain size distribution of remoulded samples}

Samples A11.1, A11.3 and A11.5 were characterised through wet sieving, sedimentation and consistency tests. All the collected samples were dried and crushed to powder. They were then prepared at water content close to the plastic limit and allowed to equilibrate for 24 hours. Particle size distribution curves are represented on Fig. 11, and in Table 3. The soil classification test results are shown in Table 3.

The clay activity of samples A11.1 and A11.5 suggests the presence of illite, confirming the X-ray identification. For sample A11.3 the low clay content precludes any reliable interpretation.

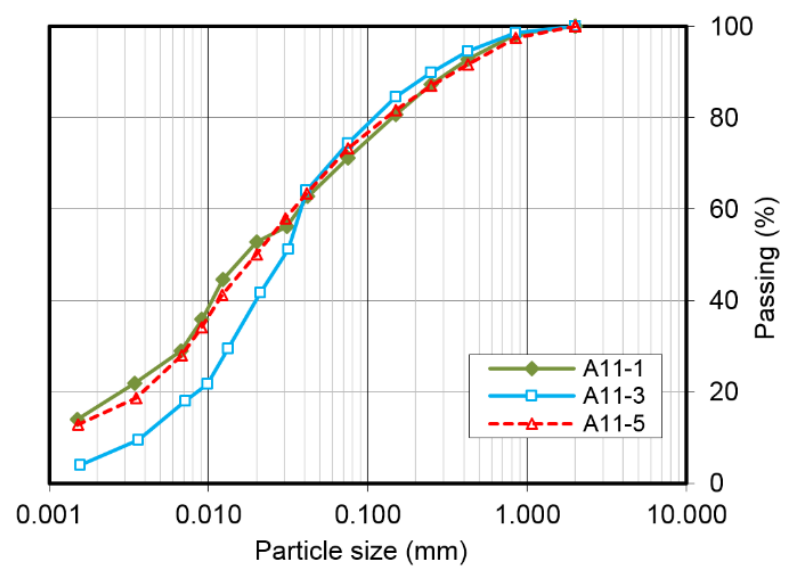

Fig. 11 Particle size distribution curves of samples 
Table 3 Soil classification test results

\begin{tabular}{|c|c|c|c|c|c|c|c|c|}
\hline \multirow{3}{*}{$\begin{array}{l}\text { Sample } \\
\mathrm{N}^{\mathrm{o}}\end{array}$} & \multirow{2}{*}{\multicolumn{3}{|c|}{$\begin{array}{c}\text { Size analysis } \\
\text { (\%) }\end{array}$}} & \multicolumn{3}{|c|}{ Consistency } & \multirow{3}{*}{ A } & \multirow{3}{*}{$\begin{array}{c}\text { Soil } \\
\text { classification }\end{array}$} \\
\hline & & & & \multicolumn{3}{|c|}{ (\%) } & & \\
\hline & Clay & Silt & Sand & $\mathrm{W}_{\mathrm{L}}$ & $\mathrm{WP}$ & PI & & \\
\hline A11.1 & 17 & 51 & 32 & 37.5 & 20.3 & 17.2 & 1.0 & Silty clay of \\
\hline A11.5 & 15 & 55 & 30 & 40 & 22.4 & 17.6 & 1.2 & $\begin{array}{c}\text { intermediate } \\
\text { plasticity }\end{array}$ \\
\hline A11.3 & 5 & 65 & 30 & 31 & 20.5 & 10.5 & 2.1 & $\begin{array}{c}\text { Silty clay of low } \\
\text { plasticity }\end{array}$ \\
\hline
\end{tabular}

$\mathrm{W}_{\mathrm{L}}$ - Liquid limit. $\mathrm{W}_{\mathrm{P}}$ - Plastic limit. PI -Plasticity index. A - activity of clay (PI/\% of clay)

\section{Ring Shear tests}

The tests were carried out in the Bromhead Ring Shear apparatus. A $5 \mathrm{~mm}$ thick annular sample with internal and external diameters of $70 \mathrm{~mm}$ and $100 \mathrm{~mm}$ respectively was placed in a lower confining ring and sheared against a roughened porous bronze platen in order to prevent slip at the soil/platen interface, such that a shear surface developed in the soil close to the upper platen. The normal load was applied via two porous bronze loading platens with a counter balance with a 10:1 ratio level loading system. A relative rotary motion was forced between the confining rings fixed to the lower platen and the upper platen by means of a motor and gearbox driving through a worm gear. A cross arm attached to the upper platen reacts against two matched proving rings, which provides a measurement of the torque transmitted through the specimen. Vertical movement of the upper loading platen can be measured by means of a single dial gauge attached to the top of the loading yoke assembly. The horizontal displacement is measured in terms of angular rotation, through a scale fixed to the turret.

The remoulded samples were prepared with a water content close to the plastic limit and allowed to equilibrate during 24 hours. The soil was kneaded evenly into the annular cavity between the confining rings using a thumb and a small spatula to minimise the possibility of trapped air. The excess soil was then levelled with the top of the confining rings. The assembly was then placed in position, on the locating studs in the turret. The water content of the excess soil was determined (Table 4).

Table 4 Initial water content of samples used in the ring shear test

\begin{tabular}{lccc}
\hline Sample $\mathrm{N}^{\mathrm{o}}$ & $\mathrm{A} 11.1$ & $\mathrm{~A} 11.3$ & $\mathrm{~A} 11.5$ \\
Initial water content (\%) & 20.2 & 25.6 & 25.0 \\
\hline
\end{tabular}

The remoulded samples were consolidated in stages up to $400 \mathrm{kPa}$, and sheared until residual strength was obtained. The maximum shear strength obtained at this stage should be close to the fully softened normally consolidated shear resistance. Residual conditions were then established by shearing at lower 
normal stresses. Table 5 presents the sequence of the several stages. The procedure used followed the methodology proposed by Lupini (1981), illustrated in Fig. 12.

Table 5 Sequence of stages used in the ring shear test

\begin{tabular}{|c|c|c|c|c|c|c|c|c|}
\hline Stage $\mathrm{N}^{\circ}$ & รี & 1 & 2 & & $3^{\#}$ & 4 & 5 & 6 \\
\hline Type & 雪 & First Shear & Shear & 营 总 & Shear & Shear & shear & Shear \\
\hline Normal stress $(\mathrm{kPa})$ & ôे & 400 & 200 & 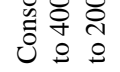 & 200 & 100 & 50 & 25 \\
\hline
\end{tabular}

\# Shear an overconsolidated $(\mathrm{OCR}=2)$ residual structure to study the shear mode.

After residual conditions were reached (stage 2), each sample was over-consolidated to $400 \mathrm{kPa}$ and the load reduced to $200 \mathrm{kPa}$ which would allow some expansion. It was then re-sheared at $200 \mathrm{kPa}$ (stage 3) and the shear mode investigated as proposed by Lupini (1981). The results showed a brittle behaviour in the first shear (Fig. 13) but no "peak" was observed in stage 3, indicating a sliding shear mode. The first shear of a normally consolidated structure shows a brittle failure. ABF, due to the clay alignment in the shear surface. Re-shearing an overconsolidated shear surface with the clay particles perfectly aligned will not show the brittle behaviour, CG. The decrease in void ratio due to overconsolidation did not create a peak as would be observed in a dense sand (CDE). Figure 13 shows the normally consolidated (fully softened) shear strength and the residual shear strength expressed in terms of the friction angle, assuming no cohesion; the values are given in Table 6.

Table 6 Normal consolidated and residual shear strength expressed in terms of the friction angle, assuming no cohesion

\begin{tabular}{lcccc}
\hline Sample $\mathrm{N}^{\circ}$ & & $\mathrm{A} 11.1$ & $\mathrm{~A} 11.5$ & $\mathrm{~A} 11.3$ \\
\hline Peak friction angle $\left(^{\circ}\right)$ & $\phi^{\prime} \mathrm{vc}$ & 18.9 & 18.7 & 23.9 \\
Residual friction angle $\left(^{\circ}\right)$ & $\phi^{\prime} \mathrm{R}$ & 13.0 & 12.0 & 19.4 \\
\hline
\end{tabular}

Following Lupini (1981), the samples A11-1 and A11-5 show a sliding mode of shear with the clay particles perfectly aligned and parallel to the shear direction. Figure 14 compares the residual shear strength obtained for the mudstones and other soils reported by Lupini et al. (1981). It can be seen that the residual shear strength of the mudstone is considerably lower than the corresponding value of other soils with the same clay fraction and plasticity. 


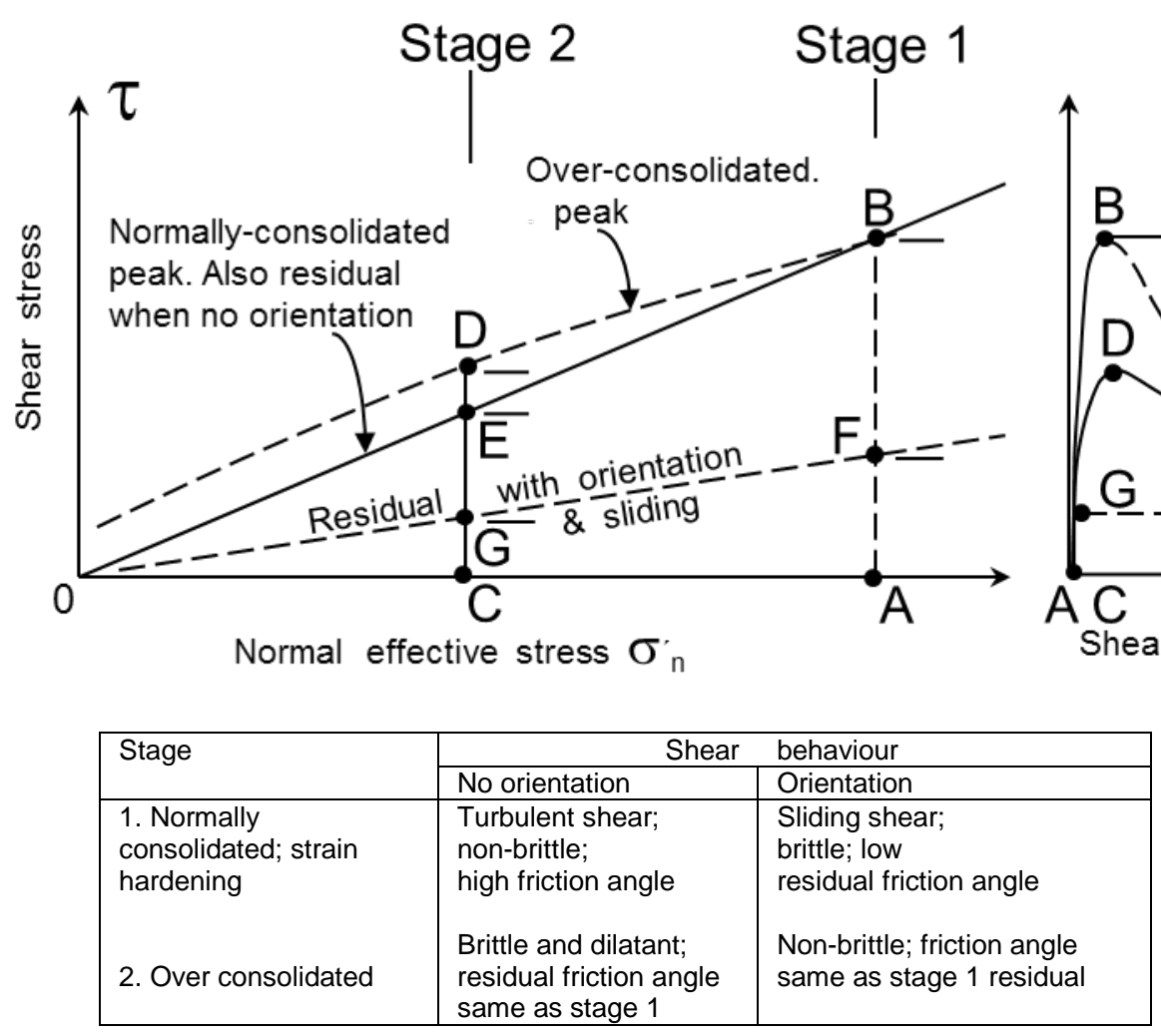

Fig. 12 Idealized behaviour on the ring shear tests according to loading sequence and mode of residual behaviour (Lupini 1981)

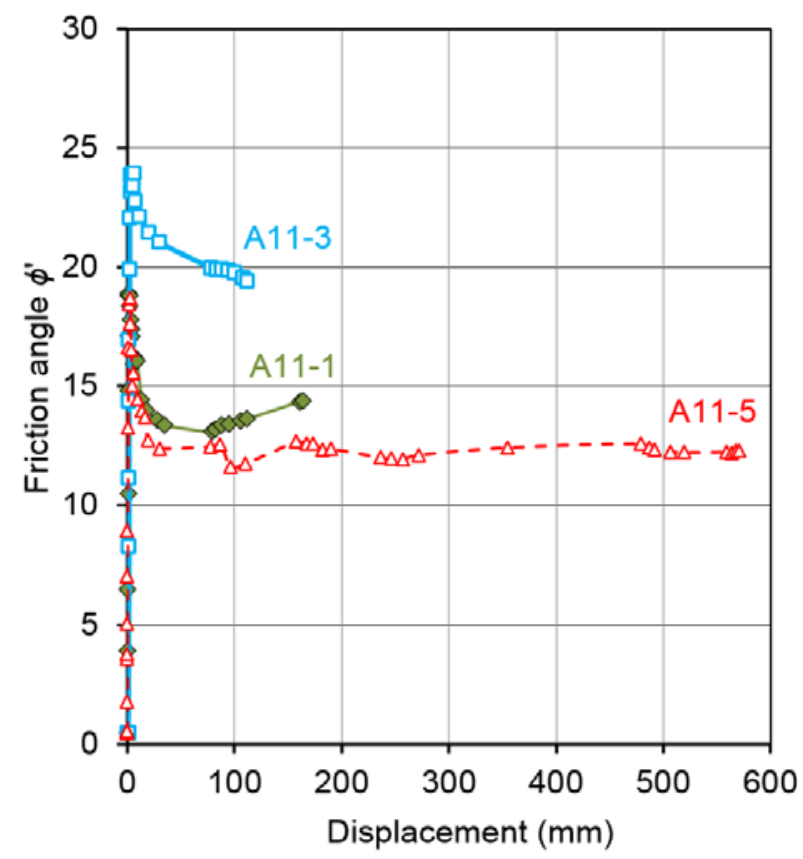

Fig. 13 First shear stages at a normal stress of $400 \mathrm{kPa}$

\section{Compressibility}

The samples were crushed to powder and distilled water was added to a value close to the liquid limit. They were then moulded into the oedometer and a consolidation test was carried out with doubled loads applied during a period of 24 hours. Tables 7 and 8 show the load steps and the parameters calculated 
for samples A11-1 and A11-3. Figure 15 presents the variation of the void ratio for two samples with effective stress using a logarithmic scale. The compression index $\left(\mathrm{C}_{c}\right)$ and the swelling index $\left(\mathrm{C}_{\mathrm{s}}\right)$ have been calculated in Table 9. Comparing the values of the void ratio obtained in the oedometer test with the values of porosity obtained from the mercury porosimeter (18.5\%), Fig. 14 and Table 9 indicate that the soils have experienced normal effective stresses as high as $15 \mathrm{MPa}$ in the past.

Table 7 Oedometer test of sample A11-1

\begin{tabular}{|c|c|c|c|c|c|c|c|c|c|}
\hline \multirow{3}{*}{$\begin{array}{c}\text { Stage } \\
\mathrm{N}^{\mathrm{o}}\end{array}$} & Efective & stress & Sample & height & \multirow[b]{3}{*}{$\mathrm{m}^{2} / \mathrm{vear}$} & \multirow[t]{2}{*}{$\mathrm{m}_{\mathrm{v}}$} & \multirow[t]{2}{*}{$\mathrm{k}$} & \multicolumn{2}{|c|}{ Void ratio } \\
\hline & Initial & Final & Initial & Final & & & & Initial & Final \\
\hline & $\mathrm{kN} / \mathrm{m}^{2}$ & $\mathrm{kN} / \mathrm{m}^{2}$ & $\mathrm{~mm}$ & $\mathrm{~mm}$ & & $\mathrm{~m}^{2} / \mathrm{kN}$ & $\mathrm{m} / \mathrm{s}$ & $\mathrm{e}_{\mathrm{i}}$ & $e_{f}$ \\
\hline 0 & & & 19.2 & 18.8 & & & & 0.939 & 0.905 \\
\hline 1 & 12.80 & 25.61 & 18.8 & 18.4 & 0.66 & $1.69 \mathrm{E}+00$ & $3.45 \mathrm{E}-10$ & 0.905 & 0.864 \\
\hline 2 & 25.61 & 51.22 & 18.4 & 17.8 & 1.05 & $1.26 \mathrm{E}+00$ & $4.11 \mathrm{E}-10$ & 0.864 & 0.804 \\
\hline 3 & 51.22 & 102.43 & 17.8 & 17.2 & 1.75 & 6.87E-01 & $3.74 \mathrm{E}-10$ & 0.804 & 0.741 \\
\hline 4 & 102.43 & 204.86 & 17.2 & 16.5 & 1.63 & 3.90E-01 & $1.98 \mathrm{E}-10$ & 0.741 & 0.671 \\
\hline 5 & 204.86 & 409.72 & 16.5 & 15.8 & 1.01 & 2.15E-01 & 6.73E-11 & 0.671 & 0.597 \\
\hline 6 & 409.72 & 819.45 & 15.8 & 15.1 & 3.30 & $1.10 \mathrm{E}-01$ & $1.13 \mathrm{E}-10$ & 0.597 & 0.526 \\
\hline 7 & 819.45 & 1638.89 & 15.1 & 14.4 & 2.33 & 5.14E-02 & 3.72E-11 & 0.526 & 0.461 \\
\hline 8 & 1638.89 & 819.45 & 14.4 & 14.5 & 5.81 & 6.36E-03 & $1.15 \mathrm{E}-11$ & 0.461 & 0.469 \\
\hline 9 & 819.45 & 409.72 & 14.5 & 14.6 & 5.87 & $1.88 \mathrm{E}-02$ & $3.44 \mathrm{E}-11$ & 0.469 & 0.480 \\
\hline
\end{tabular}

$\mathrm{C}_{\mathrm{V}}$-coefficient of consolidation, $\mathrm{k}$-coefficient of permeability, $\mathrm{m}_{\mathrm{v}}$ - volumetric coefficient of compressibility

Table 8 Oedometer test of sample A11-3

\begin{tabular}{|c|c|c|c|c|c|c|c|c|c|}
\hline \multirow{3}{*}{$\begin{array}{c}\text { Stage } \\
\mathrm{N}^{\mathrm{o}}\end{array}$} & \multicolumn{2}{|c|}{ Efective stress } & \multicolumn{2}{|c|}{ Sample height } & \multirow[t]{2}{*}{$\mathrm{C}_{\mathrm{v}}$} & \multirow[t]{2}{*}{$\mathrm{m}_{\mathrm{v}}$} & \multirow[t]{2}{*}{$\mathrm{k}$} & \multicolumn{2}{|c|}{ Void ratio } \\
\hline & Initial & Final & Initial & Final & & & & Initial & Final \\
\hline & $\mathrm{kN} / \mathrm{m}^{2}$ & $\mathrm{kN} / \mathrm{m}^{2}$ & $\mathrm{~mm}$ & $\mathrm{~mm}$ & $\mathrm{~m}^{2} /$ year & $\mathrm{m}^{2} / \mathrm{kN}$ & $\mathrm{m} / \mathrm{s}$ & $\mathrm{e}_{\mathrm{i}}$ & $e_{f}$ \\
\hline 0 & & & 19.1 & 19.0 & & & & 0.823 & 0.810 \\
\hline 1 & 12.80 & 25.61 & 19.0 & 18.7 & 2.04 & $1.14 \mathrm{E}+00$ & 7.22E-10 & 0.810 & 0.784 \\
\hline 2 & 25.61 & 51.22 & 18.7 & 18.4 & 6.25 & 7.54E-01 & 1.47E-09 & 0.784 & 0.749 \\
\hline 3 & 51.22 & 102.43 & 18.4 & 17.9 & 9.40 & 4.82E-01 & $1.41 \mathrm{E}-09$ & 0.749 & 0.706 \\
\hline 4 & 102.43 & 204.86 & 17.9 & 17.6 & 4.40 & $1.75 \mathrm{E}-01$ & 2.39E-10 & 0.706 & 0.676 \\
\hline 5 & 204.86 & 409.72 & 17.6 & 16.9 & 4.40 & 1.83E-01 & $2.50 \mathrm{E}-10$ & 0.676 & 0.613 \\
\hline 6 & 409.72 & 819.45 & 16.9 & 16.2 & 31.95 & $1.01 \mathrm{E}-01$ & 1.01E-09 & 0.613 & 0.546 \\
\hline 7 & 819.45 & 1638.89 & 16.2 & 15.7 & 14.68 & 4.33E-02 & $1.98 \mathrm{E}-10$ & 0.546 & 0.491 \\
\hline 8 & 1638.89 & 409.72 & 15.7 & 15.8 & 109.22 & 7.31E-03 & $2.48 \mathrm{E}-10$ & 0.491 & 0.504 \\
\hline 9 & 409.72 & 102.43 & 15.8 & 16.0 & 27.80 & 3.37E-02 & 2.91E-10 & 0.504 & 0.520 \\
\hline
\end{tabular}

$\mathrm{C}_{\mathrm{v}}$-coefficient of consolidation, $\mathrm{k}$-coefficient of permeability, $\mathrm{m}_{\mathrm{v}}$ - volumetric coefficient of compressibility

Table 9 Compression index $\left(\mathrm{C}_{\mathrm{c}}\right)$ and swelling index $\left(\mathrm{C}_{\mathrm{s}}\right)$ of samples

\begin{tabular}{ccc}
\hline Sample & A11-1 & A11-3 \\
\hline $\mathrm{C}_{\mathrm{c}}$ & 0.238 & 0.162 \\
$\mathrm{C}_{\mathrm{s}}$ & 0.041 & 0.024 \\
\hline
\end{tabular}



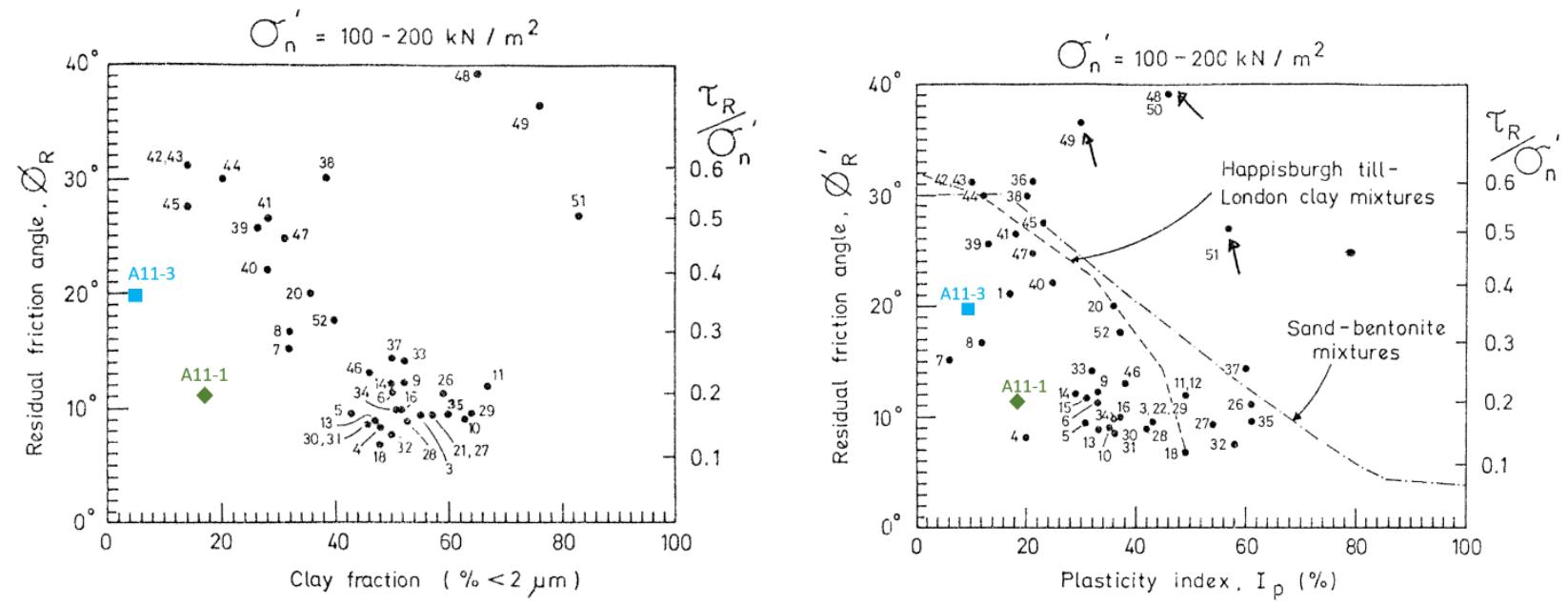

Fig. 14 Residual shear strength of the mudstones compared with other soils reported by Lupini et al. (1981)

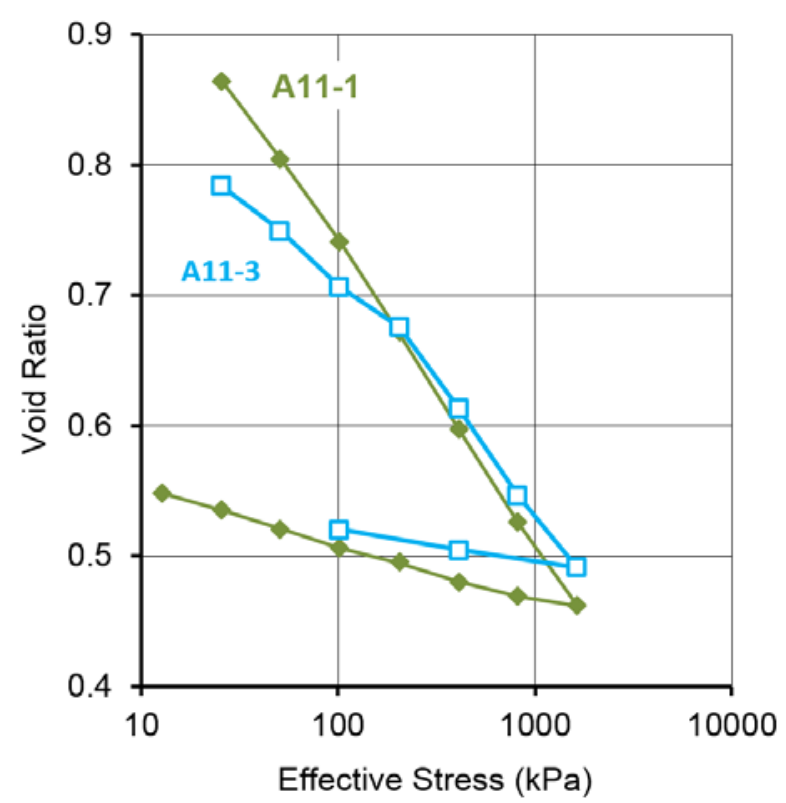

Fig. 15 Variation of the void ratio with the effective stress for two samples, A11-1 and A11-3

\section{Slope stability analysis}

As a failure of the slope close to the Areeiro roundabout (slope 4) is the most likely to cause material damage and human casualties, it was selected for analysis. Two procedures were undertaken: a kinematic analysis using the Markland (1972) method and limit equilibrium of planar failure.

\section{Kinematic analysis}

The strike, dip and roughness of 176 discontinuities on slope 4 face were determined. The stereographic projection allowed the identification of three discontinuities sets (A, B and C of Fig. 16), oriented approximately: A) $\mathrm{N} 24^{\circ} \mathrm{W} ; 15^{\circ} \mathrm{SW}$; B) $\mathrm{N} 26^{\circ} \mathrm{W} ; 67^{\circ} \mathrm{SW}$; C) $\mathrm{N} 55^{\circ} \mathrm{E} ; 82^{\circ} \mathrm{SE}$. The A set corresponds to the 
bedding and represents approximately 55\% of the identified discontinuities. The B set shows high dip angles $\left(67^{\circ}\right)$ and a strike direction similar to the A set, but with a greater dispersion. The majority of the B set is sub-parallel to the cut slope face. The $\mathrm{C}$ set is the less frequent, and has a steep dip. The strike direction displays greater dispersion, being almost perpendicular to the cut slope face.

Slope 4 is mainly formed of sandstone layers with rough surfaces. The discontinuities have a friction angle of $>35^{\circ}$ which inhibits slope failure. However, the mudstones may have a residual friction angle of $<15^{\circ}$ (Table 6), allowing the development of the planar failures observed in previous movements (Figure 16).

There is also the possibility of wedge failure due to the intersection of the A and C discontinuity sets, although the latter are less frequent. The use of the refinement to the Markland (1972) test proposed by Hocking (1976) shows that planar failure is more likely to occur than wedge failure, as confirmed by “in situ” observations.

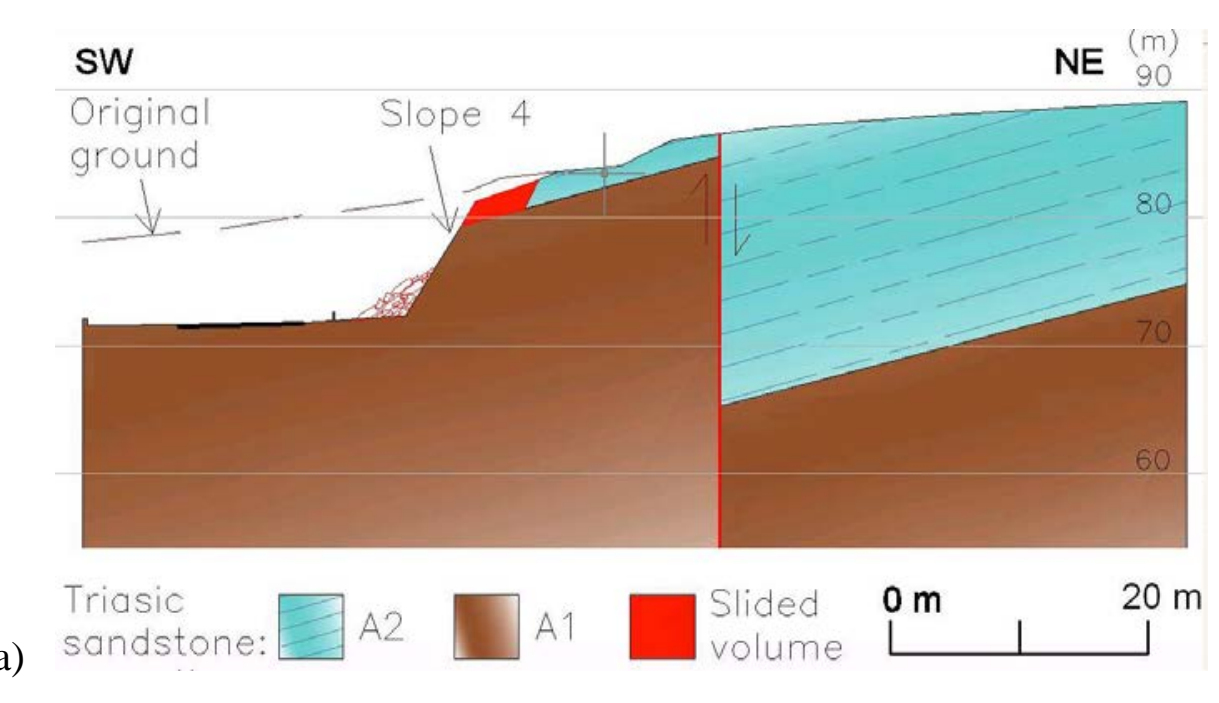

b)
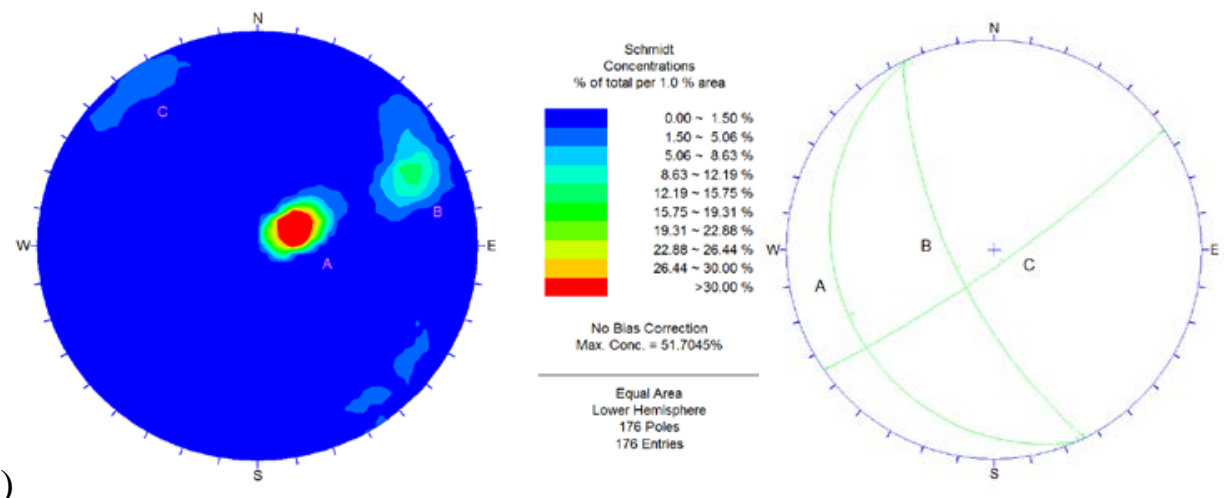

Fig. 16 Areeiro roundabout slope (slope 4): a slope cross section and $\mathbf{b}$ stereonet plot of poles and density contour diagram using the program Dips. A, B and C discontinuity sets 


\section{Limit equilibrium of planar failure}

Slope failures occurred during the winter, after a period of significant rain or as a direct consequence of soil excavation at the toe of the slope. Excavation at a toe of the slope releases strain energy and horizontal deformations occur, leading to progressive failure. In the dry hot months, stability increases due to an increase in strength at the shear surface, caused by suctions (negative pore water pressures). In the intact mudstone, based on the measured pore size, the suction can reach very high values. During the rainy season, the mudstone takes in water and the suction effect is significantly reduced. The phreatic level increases, and the positive pore water pressures build up at the shear surface, reducing the shear strength. In addition, as the fissures are filled with water, the pore water pressure increases, creating an additional horizontal driving force such that stability is further decreased.

A sensitivity study was carried out based on the morphology, geology and shear strength parameters obtained in the ring shear tests. Based on the porosity measurement and the oedometer tests carried out, normal stresses of around $15 \mathrm{MPa}$ must have been be applied in the past to result in the void ratios of 0.229 obtained in the mercury porosimeter tests and it can be assumed that a shear resistance of thousands of kilopascals will exist in the unfissured intact material.

The soil in the shear zone is highly fissured, which significantly decreases its shear strength while the friction angle approaches the residual strength, as shown by Skempton $(1964,1985)$. Hawkins \& McDonald (1992) also draw attention to the fact that a curved failure envelope, tend to a zero cohesion at very low effective stresses. In the present work, the cohesion is assumed zero and because the soil is not fully saturated, it will develop negative pore pressures. A sustainable suction in the fissures will be, at most, up to $100 \mathrm{kPa}$.

The sensitive analysis assumed a block moving over a thin bed of mudstone containing a shear surface inclined at $16^{\circ}$ to the horizontal (Skempton \& DeLory, 1957). The block was around $8 \mathrm{~m}$ long and included an extension fissure extending $2 \mathrm{~m}$ from the top of the block. The following conditions were studied:

i. $\quad$ Constant shear strength along the shear surface of $9 \mathrm{kPa}$ will guarantee a factor of safety of 1 . An unconsolidated quick shear box test $(1 \mathrm{~mm} / \mathrm{min})$ carried out on an intact sample showed a shear resistance of $30 \mathrm{kPa}$. For this value, a factor of safety of 3.4 is obtained.

ii. Shear strength on the shear surface controlled by the normally consolidated angle of shear resistance $\left(19^{\circ}\right)$, cohesion zero and a suction of about $20 \mathrm{kPa}$. A factor of safety equal to 2.0 was obtained.

iii. Shear strength on the shear surface controlled by the normally consolidated angle of shear resistance $\left(19^{\circ}\right)$ and no pore water pressures. A factor of safety of 1.2 was obtained. 
iv. Shear strength on the shear surface controlled by the normally consolidated angle of shear resistance and pore water pressures varying linearly along the shear surface, corresponding to an increase of the phreatic level or to water entering the fissure, just sufficient to bring the factor of safety equal to unity. The mean height of water above the shear surface was $40 \mathrm{~cm}$.

The fully softened angle of shear strength of $19^{\circ}$ will guarantee a factor of safety of 1.2, and a mean angle of shear strength along the shear surface of $16^{\circ}$ will bring the slope to the state of failure. This is caused by progressive failure due to elastic lateral strain release or by creep as a result of pore pressure fluctuation which will destroy any cohesion and result in an angle of shear strength along the shear surface with values between $19^{\circ}$ (fully softened) and $12^{\circ}$ (residual strength). Failure could be triggered by a build-up of pore water pressures as shown in (iv), accelerated by the decrease of the shear strength to a residual state. During dry weather, the slope will be safe as suction values as low as $20 \mathrm{kPa}$ resulting in safety factors of around 2.0.

\section{Final considerations}

The cut slopes analysed are mainly composed of Triassic red siliceous sandstone, interbedded with thin mudstone layers, gently dipping to the west. While the sandstone was formed by fluvial deposition, the mudstone layers accumulated in a shallow lacustrine environment.

Based on the laboratory tests results it was concluded that a stress of 15 MPa must have been applied to the mudstone layers in the past. As the mudstone tested belongs to the base of the unit A2 of the Conrarria Formation, $15 \mathrm{MPa}$ is roughly equivalent to an overburden thickness of $70 \mathrm{~m}$. Based on the geological information it is expectable that before erosion, unit A2 had a total thickness of around $80 \mathrm{~m}$ (Palain 1976), which is in consistent the computed 15 MPa.

The geomorphology and tectonic activity in the area resulted in an irregular distribution of the lithologies; the most significant being the distribution of the mudstones responsible for the slope failures. The stratigraphy and structural geology allowed the identification of the mudstone layers and helped to elucidate the landslide occurrences. Comparing the opposite sides of the valley (Areeiro on the east and "Quinta da Portela” on the west), it is possible to conclude that the geological structure, the geomorphology and the characteristics of the mudstones are the main factors influencing the occurrence of landslides. As verified “in situ”, this conjugation of factors favours failures along low dip layers toward the cut slope face, on the east side of the valley in Areeiro, even with cut slopes only a few meters high. The same factors are responsible for the more stable conditions on the west side of the 
valley, in Quinta da Portela, where the layers dip into the face of the excavations, such that slopes of $>20 \mathrm{~m}$ high can remain stable.

For the sandstone, as the strata dip is lower than the internal friction angle, planar failures cannot develop. Conversely, the weathered mudstone layers may have a residual friction angle lower than the bedding angle, allowing the development of slope failures when pore pressure rises. The degradation of the mudstones over time can be difficult to assess but will affect the safety factor of the Areeiro slopes with the progressive unloading of the rock mass, mainly at the cut slope face, and the variation in pore pressure. When weathered, the angle of shear strength of the mudstone can vary between fully softened $\left(19^{\circ}\right)$ and residual $\left(12^{\circ}\right)$. Suction is removed with the rise of pore pressures, and when the water column is higher than $0.4 \mathrm{~m}$ above the shear surface, the conditions necessary for sliding occur (Skempton \& DeLory, 1957).

As landslides may occur in areas that show no evidence of instability, the areas adjacent to the Areeiro's School and to the Areeiro roundabout warrant special attention including detailed monitoring of the slope. In the Areeiro cut slopes, some stabilization measures are recommended to avoid dilation of the mudstone and to drain the groundmass to avoid the build-up of pore pressures.

\section{Acknowledgments}

This work was funded by the Portuguese Government through FCT -Fundação para a Ciência e a Tecnologia under the project PEst-OE/CTE/UI0073/2011 of the Geosciences Center.

\section{References}

Azerêdo AC, Duarte LV, Henriques MH and Manuppella G (2003) Da dinâmica continental no Trásico aos mares do Jurássico Inferior e Médio. Instituto Geológico e Mineiro, 43p (in portuguese)

Chleborad A (2000) Preliminary method for anticipating the occurrence of precipitation-induced landslides in Seattle, Washington. Open-File Report 00-469, U.S. Geological Survey

Hawkins, AB \& McDonald, C (1992) Decalcification and residual shear strength reduction in Fuller's Earth Clay. Géotechnique 42(3):453-464

Hocking GA (1976) Method for distinguishing between single and double plane sliding of tetrahedral wedges. International Journal of Rock Mechanics and Mining Science and Geomechanics 13:225-226

ISRM (2007) Sugested Methods for Determining Water Content, Porosity, Density, Absorption and Related Properties and Swelling and Slake-Durability Index Properties. In: Ulusay and Hudson (eds) The complete ISRM suggested methods for rock characterization, testing and monitoring: 1974-2006. ISRM Turkish National Group, Ankara, Turkey, pp 143-156. 
Lemos LL, Quinta-Ferreira, M (2004) Elísio de Moura landslide. In: Lacerda, Ehrlich, Fontoura \& Sayão (eds) Landslides: Evaluation and Stabilization. Balkema, 2:1013-1017

Lupini JF (1981) The residual strength of soils, PhD thesis, University of London

Lupini JF, Skinner AE and Vaughan PR (1981) The drained residual strength of cohesive soils. Géotechnique 31(2):181-213

Markland JT (1972) A useful technique for estimating the stability of rock slopes when the rigid wedge slip type of failure is expected. Imperial College Rock Mechanics Research Reprints 19:1-10

Miranda J, Pina B, Matos V, Calhôa AM, Pena dos Reis R, Pimentel N (2010) Estudo das fácies de leque aluvial em afloramento do Triásico Superior de Coimbra. e-Terra 21(9):4p (in portuguese)

Mitchell, JK (1993) Fundamentals of soil behavior. $2^{\text {nd }}$ ed. John Wiley \& Sons, New York

Palain C (1976) Une série détritique terrigène. Les “Grés de Silves”: Trias et Lias inférieur du Portugal. Memórias, Serviços Geológicos de Portugal, Lisboa. 25 (nova série), 377p

Quinta-Ferreira M (2007) Natural and man made causes for the Elísio de Moura soil flow in Coimbra, Portugal. Bull Eng Geol Environ 66(1):35-43. DOI 10.1007/s10064-006-0046-1

Quinta-Ferreira M, Lemos LL, Pereira LM (2005) Influência da precipitação na ocorrência de deslizamentos em Coimbra, nos últimos 139 anos. Geotecnia 104:17-30 (in portuguese)

Quinta-Ferreira M, Lemos LL, Pereira LM (2006) Influência da precipitação nos deslizamentos e no comportamento dos pelitos do Triásico, em Coimbra”. 10 Cong. Nacional de Geotecnia 1:61-72. Sociedade Portuguesa de Geotecnia (in portuguese)

Quinta-Ferreira M, Quinta-Ferreira T (2004) O problema das instabilizações de taludes em Coimbra. Cadernos de Geografia 21/23:127-142 (in portuguese)

Quinta-Ferreira M, Velho JL, Pereira LM (2004) Avaliação das características evolutivas dos pelitos do Triássico em Coimbra. $9^{\circ}$ Congresso Nacional de Geotecnia 1:39-50 (in portuguese)

Schuster RL, Highland LM (2007) The Third Hans Cloos Lecture. Urban landslides: socioeconomic impacts and overview of mitigative strategies. Bull Eng Geol Environ 66:1-27. DOI 10.1007/s10064-006-0080-z

Skempton AW (1964) Long-term stability of clay slopes. Géotechnique 14(2):75-101

Skempton AW (1985) Residual strength of clays in landslides, folded strata and the laboratory. Géotechnique 35(1):3-18

Skempton AW, DeLory FA (1957) Stability of natural slopes in London clay. Proc $4^{\text {th }}$ Int Conf Soil Mechanics and Foundation Engineering, London, 2:378-381

Soares AF et al. (2007) Folha 19-D, Coimbra-Lousã. Escala 1:50 000. INETI, Departamento de Geologia, Lisboa (in portuguese) 